\title{
The sarolga: conservation implications of genetic and visual evidence for hybridization between the brolga Antigone rubicunda and the Australian sarus crane Antigone antigone gillae
}

\author{
Timothy D. Nevard, Martin Haase, George Archibald \\ IAN Leiper and StePhen T. Garnett
}

\begin{abstract}
To investigate the extent of suspected hybridization between the brolga Antigone rubicunda and the Australian sarus crane Antigone antigone gillae, first noted in the 1970s, we analysed the genetic diversity of 389 feathers collected from breeding and flocking areas in north Queensland, Australia. We compared these with 15 samples from birds of known identity, or that were phenotypically typical. Bayesian clustering based on 10 microsatellite loci identified nine admixed birds, confirming that Australian cranes hybridize in the wild. Four of these were backcrosses, also confirming that wild Australian crane hybrids are fertile. Genetic analyses identified 10 times more hybrids than our accompanying visual field observations. Our analyses also provide the first definitive evidence that both brolgas and sarus cranes migrate between the Gulf Plains, the principal breeding area for sarus cranes, and major non-breeding locations on the Atherton Tablelands. We suggest that genetic analysis of shed feathers could potentially offer a cost-effective means to provide ongoing monitoring of this migration. The first observations of hybrids coincided with significantly increased opportunities for interaction between the two species when foraging on agricultural crops, which have developed significantly in the Atherton Tablelands flocking area since the 1960s. As the sarus crane is declining in much of its Asian range, challenges to the genetic integrity of the Australian sarus crane populations have international conservation significance.
\end{abstract}

Keywords Antigone antigone gillae, Antigone rubicunda, Australian sarus crane, brolga, evolution, hybridization, introgression, migration monitoring

\footnotetext{
Timothy D. Nevard* (Corresponding author, (1) orcid.org/0000-0002-12874595) Ian Leiper and Stephen T. Garnett Research Institute for the Environment and Livelihoods, Charles Darwin University, Darwin, Northern Territory 0909, Australia. E-mail tnevard@woothakata.com

Martin HAase AG Vogelwarte, Zoologisches Institut und Museum, Universität Greifswald, Greifswald, Germany

George Archibald International Crane Foundation, Baraboo, Wisconsin, USA

*Also at: Wildlife Conservancy of Tropical Queensland, Ravenshoe, Queensland, Australia

Received 19 October 2017. Revision requested 5 February 2018.

Accepted 16 May 2018. First published online 6 May 2019.
}

\section{Introduction}

Tybridization between apparently well-differentiated 1 species is a commonly observed phenomenon and is widely studied in the context of speciation and reproductive isolation among species (Arnold, 1997; Pennisi, 2016). Hybridization has a variety of evolutionary consequences, depending on the fitness of the hybrids, which may range from sterility and reduced fertility, to hybrid vigour or heterosis, whereby hybrid individuals perform better and out-compete parental species (Burke \& Arnold, 2001; Pennisi, 2016). As a consequence, if species are rare and locally confined (Rhymer \& Simberloff, 1996), genetic mixing can lead to the extinction of one or both parental species (Todesco et al., 2016). Eventually, hybridization can lead to speciation, with two parental species giving rise to a new species (Dowling \& Secor, 1997; Soltis \& Soltis, 2009), highlighting the relevance of studying hybridization from the perspective of conservation biology. Allendorf et al. (2001) noted that taxa that have arisen through natural hybridization warrant protection. However, they also noted that increased anthropogenically related hybridization is causing extinction of many taxa (species, subspecies and locally adapted populations) by both replacement and genetic mixing, and they argued that hybrid taxa resulting from anthropogenic causes should therefore be protected only in exceptional circumstances. We do not yet know if hybrids of the brolga Antigone rubicunda and the Australian sarus crane Antigone antigone gillae have arisen as a result of anthropogenic habitat change, nor if agricultural and conservation policy has the potential to curtail this, but it is a matter for careful consideration. The starting point for this is gaining an appreciation of the scale of hybridization. Depending on the interaction of parental alleles, and their dominance patterns as well as epistatic effects, hybrid individuals need not be phenotypically intermediate between their parents (Rieseberg et al., 1999). Also, introgression of alleles from one species into the other need not be symmetrical, as demonstrated in many cases of mitochondrial introgression (Toews \& Brelsford, 2012). On the nuclear level, genomic data indicate that hybridization and introgression interacting with recombination and selection result in much more complex scenarios of genetic diversity (Payseur \& Rieseberg, 2016). 


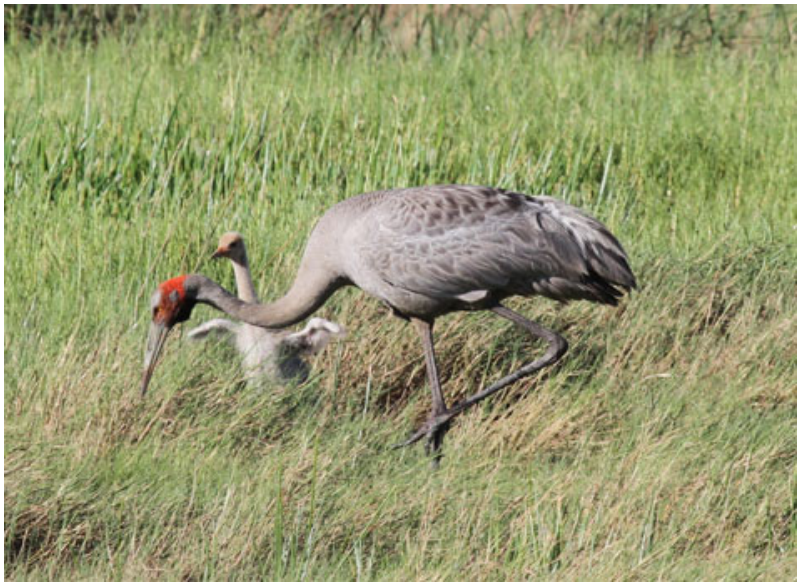

Plate 1 Typical brolga Antigone rubicunda (small red skull-cap type comb, dark wattle and grey legs), with unfledged chick, in Gulf Plains, Australia (Fig. 1). (Photo: T. Nevard)

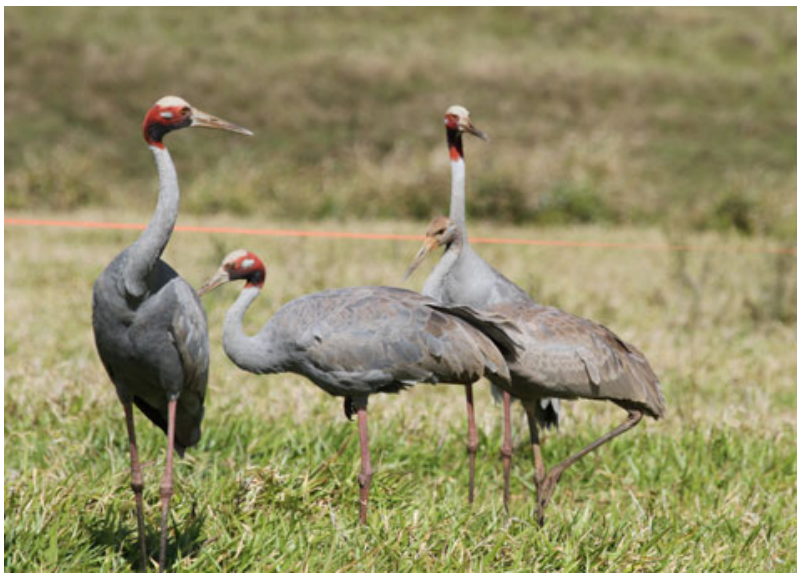

Plate 2 Typical Australian sarus cranes Antigone antigone gillae (pink legs, red comb extending down the neck, whitish crown and darker grey colour), with first-year juvenile, in Atherton Tablelands, Australia (Fig. 1). (Photo: T. Nevard)

Secondary contact of taxa that are well differentiated in allopatry may result in hybridization (Grant \& Grant, 2016; Vijay et al., 2016), even among non-sister species (Koch et al., 2017). Such is the situation for the two Australian cranes, the brolga (Plate 1) and the Australian subspecies of the sarus crane (Plate 2). The brolga, which is endemic to Australasia (Australia and New Guinea), probably split from a common ancestor with the sarus crane 3.3-4.9 million years ago (Krajewski et al., 2010). Sarus cranes, whose range includes South and South-east Asia (Fig. 1), were first recorded in Australia in the 1960 s (Gill, 1967) but may have been isolated from Asian populations for up to 37,500 years (Wood \& Krajewski, 1996).

Hybridization between the brolga and sarus crane was first noted in French aviculture in 1934 (Gray, 1958), when

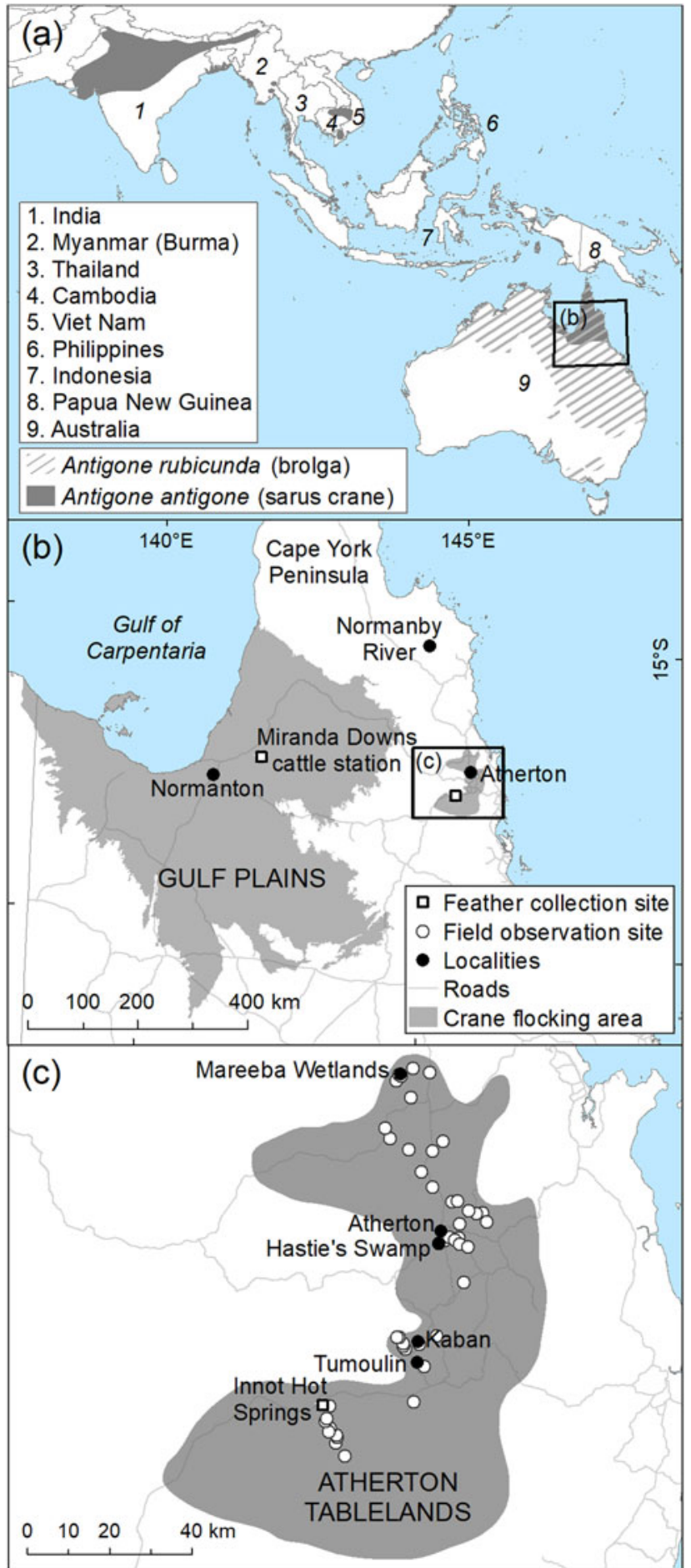

FIg. 1 (a) Global distribution of the brolga Antigone rubicunda and the sarus crane Antigone antigone, and data collection sites in (b) the Gulf Plains and (c) Atherton Tablelands, Australia. Distribution data derived from BirdLife International and NatureServe Bird Species Distribution Maps of the World (2014) and The Australian Bird Guide (Menkhorst et al., 2017). Gulf Plains Interim Biological Regionalization Area derived from Department of Environment \& Energy (2012), and state roads from Department of Transport \& Main Roads (2016). 
fertile hybrids between the brolga and the South-east Asian subspecies of the sarus crane Antigone antigone sharpii were produced. In 1972, when observing the flocking behaviour of brolgas and sarus cranes on the Atherton Tablelands in Queensland, Australia, Archibald (1981) identified at least two and possibly six potential hybrids (for which he coined the name sarolga), and speculated that if hybridization were to increase, introgression could be significant in the conservation of cranes in Australia. Similar concerns led Jones et al. (2005) to recommend monitoring of the genetic integrity of Australian sarus cranes. The present research is the first to confirm and quantify the extent of natural hybridization between the brolga and the Australian sarus crane.

\section{Brolga}

In Australia the brolga occurs across the north of the country in Queensland, the Northern Territory and Western Australia, and as far south as Victoria, where it is threatened (Marchant \& Higgins, 1993; Fig. 1a). In Queensland the species has been recorded throughout the state (Marchant \& Higgins, 1993) but is now widespread and abundant only in the north. Although breeding occurs throughout its Queensland range (Marchant \& Higgins, 1993; Barrett et al., 2003), it appears to be focused on the grasslands and open savannah woodland of the Gulf Plains, south-east of the Gulf of Carpentaria and in Cape York Peninsula. Scattered breeding occurs elsewhere, with flocking (non-breeding) regions including the Atherton Tablelands and south of Townsville on the north-east coast of Queensland (Lavery \& Blackman, 1969).

The brolga population in northern Australia is generally considered to be stable and was estimated to comprise 20,000-100,000 individuals (Meine \& Archibald, 1996). A total of 51,969 brolgas were recorded by Kingsford et al. (2012), and all but 135 of these were in northern Australia. The only longitudinal counts are from north-east Queensland (Atherton Tablelands and Townsville regions), with an annual mean of c. 800 individuals recorded by communitybased naturalists during 1997-2017, with a peak of c. 2,000 in 2005 (E. Scambler, pers. comm.).

The dispersal patterns and movements of brolgas across their range are poorly understood (Marchant \& Higgins, 1993). Brolgas undertake seasonal movements between breeding and non-breeding (flocking) habitats in response to rain and flooding (Marchant \& Higgins, 1993). Flocks are formed during the dry season and pairs disperse to breeding sites in the wet season. Although there is an increasing body of work on the species in the southern part of its range, especially in Victoria (Harding, 2001; Herring, 2005, 2007), knowledge of the behaviour and ecology of tropical brolgas remains largely confined to earlier studies, such as those of Hughes \& Blackman (1973). Brolgas can use brackish waters, having a unique salt-gland, and when observed with sarus cranes near Normanton, brolgas favoured deeper, generally coastal marshes (Walkinshaw, 1973). However, they also occur in open forest and woodland, grassland and cultivated land (Lavery \& Blackman, 1969).

\section{Australian sarus crane}

Although the sarus crane is primarily a South Asian species, it is extinct in the Philippines and declining in much of its Asian range, particularly in Burma, Thailand and Indochina (Meine \& Archibald, 1996; Archibald et al., 2003), and is categorized as Vulnerable on the IUCN Red List (BirdLife International, 2016). The Australian sarus crane population is therefore of international conservation significance and hybridization with the brolga could potentially be a threat to the genetic integrity of the Australian subspecies.

Sarus cranes in Australia are almost entirely confined to Queensland (Fig. 1a), with known breeding areas along the Gulf Plains and on the Normanby River floodplains in eastern Cape York Peninsula (Marchant \& Higgins, 1993; Barrett et al., 2003; Franklin, 2008). Most breeding records are from the Gulf Plains and concentrated in the Gilbert and Norman River catchments, where cranes make use of both natural and man-made wetlands on cattle properties (Barrett et al., 2003). The only known major dry-season flocking area for sarus cranes is the Atherton Tablelands and its immediate vicinity. Counts of dry-season flocks on the Atherton Tablelands provide the only current estimates of sarus crane recruitment rates (Marchant \& Higgins, 1993; Grant, 2005). An unknown proportion of the sarus crane population remains on the Gulf Plains and the adjacent inland area in the dry season, and therefore utilizes different landscapes and food types during this period, as there are no significant cropped areas. Migration routes followed by sarus cranes to the Atherton Tablelands from their breeding areas, and their habitat usage along the way, are currently unknown. The importance of migration routes is becoming increasingly understood, as knowledge of breeding and non-breeding locations alone is insufficient to secure the protection of migratory species (Runge et al., 2014).

Estimates of total numbers of Australian sarus cranes have varied from 5,000 to 10,000 individuals (E. Scambler, pers. comm.), but these have low reliability (Garnett \& Crowley, 2000). Annual (unpublished) counts undertaken by local members of BirdLife Australia on the Atherton Tablelands (E. Scambler, pers. comm.) indicate $800-1,500$ individuals flocking in dry seasons during 1997-2017 but it is not known what proportion of the total Australian sarus crane population these birds represent. There are no current estimates of population trends in Australia (E. Scambler, pers. comm.), but it is thought that numbers of sarus cranes have increased from perhaps as few as 200 on the Atherton Tablelands in the late 196os (G. Archibald, pers. obs.). 


\section{Aims}

Although the presence of putative hybrid cranes on the Atherton Tablelands has been noted by experienced observers for many years, we hypothesized that it is possible that these were non-hybrid birds, exhibiting intrinsic phenotypic variability. We were therefore interested in testing the degree of introgression (if any) in the crane population, as well as providing a benchmark for its future measurement both visually and genetically. To do this we needed to understand whether birds with the visual characteristics that had led observers to believe that they were hybrids (sarolgas) were, in fact, hybrids.

We aimed to (1) establish the extent of hybridization between the Australian sarus crane and the brolga, using molecular methods; (2) seek evidence from these genetic data for the presumed connectivity of breeding and flocking areas in the Gulf Plains and Atherton Tablelands; (3) describe the distribution of individuals with hybrid characteristics on the Atherton Tablelands; and (4) discuss the results primarily with respect to their relevance to biological conservation of the two species in Australia.

\section{Methods}

\section{Field observations and sample collection}

We observed cranes during July 2013-June 2016 in 51 monthly circuits of $334.7 \mathrm{~km}$ that encompassed 46 foraging sites distributed across all known crane flocking areas of the Atherton Tablelands (Figs $1 \mathrm{~d} \&$ 2), which were visible from the road. At each site we counted adult and first-year juvenile brolgas and sarus cranes using $10 \times 40$ binoculars, and examined potential hybrids (see below and Plate 3) using a $50 \times$ spotting scope. Individuals could not be distinguished and were probably counted on multiple occasions and at multiple sites. However, enough cranes were counted that there is no reason to suspect systematic bias in the estimate of the proportion of visually distinguishable hybrids amongst the wider crane population.

The initial identification of hybrids was based on the presence of at least four readily observable characteristics including at least two of (1), (4) and (6) in Archibald's (1981) typology of sarolgas: (1) larger and heavier than either parent species; (2) an irregular border to the comb; (3) notches in the cap; (4) intermediate or mixed-colour legs; (5) a scalloped mantle; (6) brighter yellow eyes than typical sarus cranes (which are more orange); and (7) a small wattle. Although Archibald's (1981) typology was helpful, in overall appearance the sarolgas he described were more like atypical sarus cranes than atypical brolgas, whereas we also observed putative hybrids that looked more like atypical brolgas (Plate $3 \mathrm{~b}$ ).
In May 2014, freshly shed feathers were collected opportunistically from Miranda Downs cattle station $\left(17^{\circ} 19.755^{\prime} \mathrm{S}\right.$, $141^{\circ} 52.77 \mathrm{O}^{\prime} \mathrm{E}$, elevation $55 \mathrm{~m}$ ) on the Gulf Plains, and in September 2015 from Innot Hot Springs $\left(17^{\circ} 43.749^{\prime}\right.$ S, $\left.145^{\circ} 16.302^{\prime} \mathrm{E}, 628 \mathrm{~m}\right)$ on the southern edge of the Atherton Tablelands (Fig. 1c). Only feathers with minimal contamination from soil and vegetation were selected and were picked from dry ground, using forceps, placed immediately in sealed plastic bags and refrigerated prior to analysis.

\section{Molecular analysis}

A total of 389 feathers were collected and prepared for genotyping: 187 from the Gulf Plains and 202 from the Atherton Tablelands. Fifteen samples (blood, feathers) were taken from reference birds, which were either phenotypically typical or for which a potential history of contact with the other species could be excluded or minimized ( $3 \mathrm{~A}$. antigone antigone, $7 \mathrm{~A}$. antigone gillae, $5 \mathrm{~A}$. rubicunda; Table 1; note that including the non-Australian A. antigone antigone in the reference collection does not affect the veracity of the comparison with brolga). DNA was extracted using the slightly modified sodium dodecyl sulphate/salting-out protocol of Miller et al. (1988). To increase the yield, dithiothreitol and Roti-PinkDNA (Carl Roth, Karlsruhe, Germany) were added. Initially we tested the 22 microsatellite loci that had been used successfully for other species of crane (Hasegawa et al., 2000; Meares et al., 2009) as well as the sarus crane (Jones et al., 2005) and the brolga (Miller, 2016). Of these, 10 could be consistently amplified and scored (Table 2). Polymerase chain reactions (PCRs) were conducted in a volume of $10 \mu \mathrm{l}$ and contained $1 \mu \mathrm{l}$ DNA (10-25 ng), $1 \mu \mathrm{l}$ of $10 \times \mathrm{NH}_{4}$-based reaction buffer, 1.5-2.25 $\mathrm{mM} \mathrm{MgCl}_{2}$ solution (Table 2), $0.25 \mathrm{mM}$ of each primer, $0.2 \mathrm{mM}$ of dNTP, $0.04 \mu \mathrm{l}$ of BioTaq DNA polymerase $(5 \mathrm{U} / \mu \mathrm{l}), 0.6 \mu \mathrm{l}$ of $1 \%$ bovine serum albumin and sterile $\mathrm{ddH}_{2} \mathrm{O}$. For two loci, GR22 and GR25, we used the MyTaq mix (all products from Bioline, London, UK). The PCR profile comprised an initial denaturation at $94^{\circ} \mathrm{C}, 36$ cycles including denaturation at $94^{\circ} \mathrm{C}$, primer specific annealing (Table 2) and extension at $72^{\circ} \mathrm{C}$, each for $30 \mathrm{~s}$, and a final elongation at $72{ }^{\circ} \mathrm{C}$ for 10 minutes. Microsatellite alleles were separated on a $3130 x \mathrm{l}$ Genetic Analyzer, together with the GeneScan 600 LIZ Size Standard 2.0 (Applied Biosystems, Waltham, USA). Fragment sizes were determined manually to avoid the inconsistencies in automatic calling that result from the arbitrariness of bin width definitions using GeneMapper 4.0 (Applied Biosystems, Waltham, USA). To control the accuracy of size determination we repeated PCRs of samples that initially gave weak signals or had rare variants. In other cases, problematic PCR samples that were initially typed in different runs, and therefore possibly difficult to calibrate, were loaded on the same plate to improve comparability. 


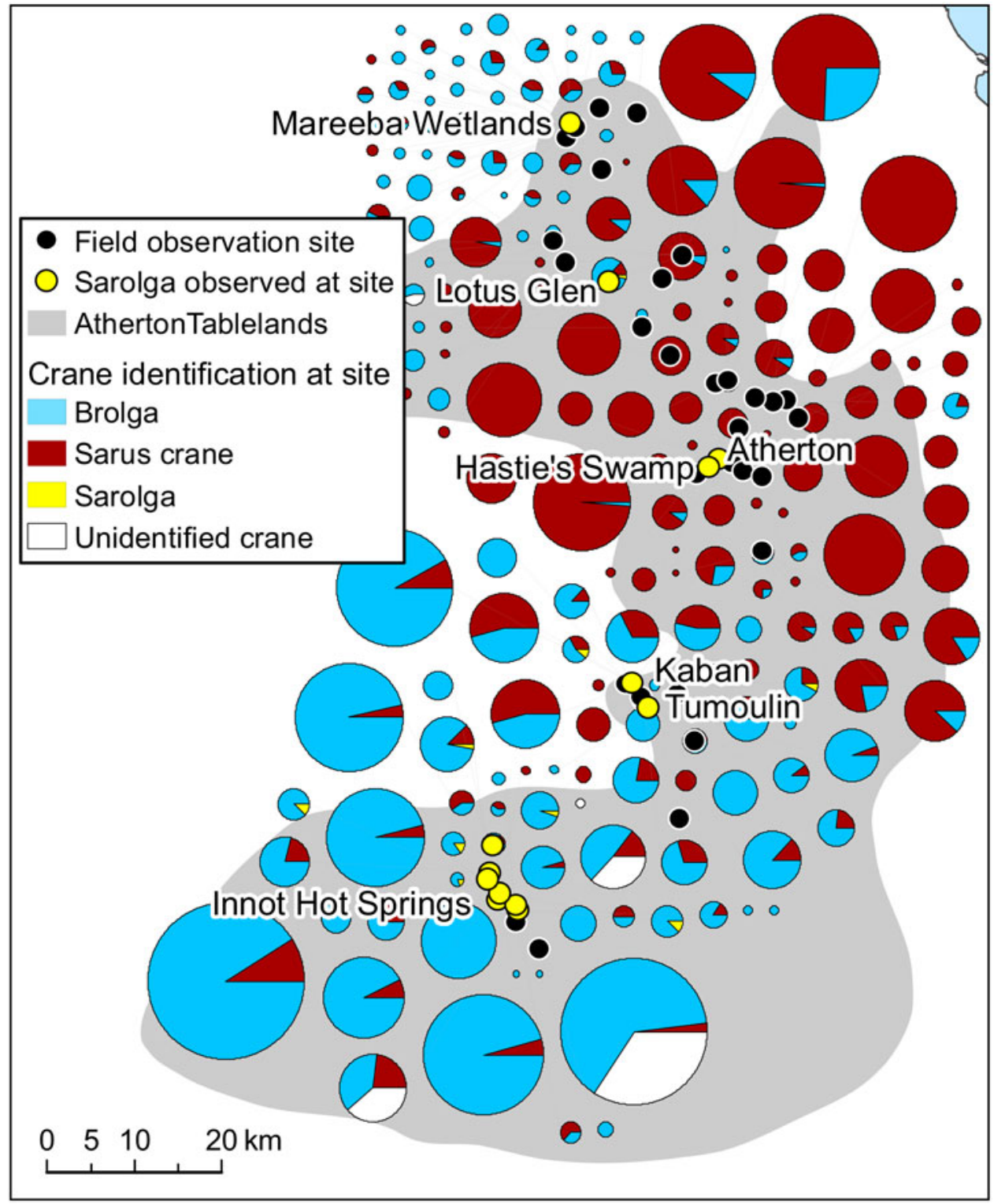

FIG. 2 Distribution and clustering of brolga, sarus crane and sarolga visually identified at 46 sites on the Atherton Tablelands (Fig. 1) during 2013-2016. On some occasions, as a result of poor light and weather conditions, cranes could not be identified.

TABLE 1 Notes on 15 reference individuals of the sarus cranes Antigone antigone antigone and Antigone antigone gillae and the brolga Antigone rubicunda from which samples were taken for molecular analysis. Samples were taken from living or recently deceased wild birds that were phenotypically typical, or from birds whose lineages of descent were known not to have had contact with the other species.

\begin{tabular}{|c|c|c|c|}
\hline Species & $\begin{array}{l}\text { No. of } \\
\text { specimens }\end{array}$ & Locality & Notes \\
\hline A. antigone antigone & 3 & $\begin{array}{l}\text { Lemgo Avicultural Collection, } \\
\text { Germany }\end{array}$ & $\begin{array}{l}\text { Breeding records show no interbreeding with other sarus } \\
\text { subspecies since their ancestors were collected from the wild } \\
\text { in the } 1970 \text { s }\end{array}$ \\
\hline A. antigone gillae & 5 & $\begin{array}{l}\text { Lemgo Avicultural Collection, } \\
\text { Germany }\end{array}$ & $\begin{array}{l}\text { Breeding records show no interbreeding since their ancestors } \\
\text { were collected from the wild in the } 1970 \text { s }\end{array}$ \\
\hline A. antigone gillae & 2 & Kairi, Queensland, Australia & Wild birds; phenotypically typical sarus cranes \\
\hline A. rubicunda & 3 & $\begin{array}{l}\text { Cairns Tropical Zoo, } \\
\text { Queensland, Australia }\end{array}$ & $\begin{array}{l}\text { Breeding records show no interbreeding since collected from } \\
\text { a wild population with no history of contact with sarus cranes }\end{array}$ \\
\hline A. rubicunda & 2 & $\begin{array}{l}\text { Herbert River, Atherton } \\
\text { Tablelands, } \\
\text { Queensland, Australia }\end{array}$ & Wild birds; phenotypically typical brolgas \\
\hline
\end{tabular}


TABLE 2 PCR specifications, genetic diversity and allele richness of microsatellite loci of brolgas and sarus cranes from the Gulf Plains (Gulf) and Atherton Tablelands (Table), Australia (Fig. 1), with locus/dye (fluorophore at $5^{\prime}$-end of forward primer), $\mathrm{MgCl}_{2}$ concentration, annealing temperature $(\mathrm{T})$, number of alleles, genetic diversity and allelic richness. The following loci could not be consistently amplified

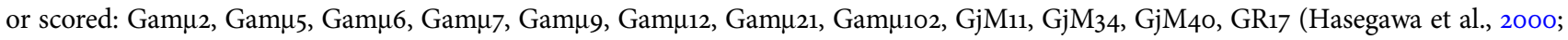
Meares et al., 2009; Miller, 2016).

\begin{tabular}{|c|c|c|c|c|c|c|c|c|c|c|c|c|}
\hline \multirow[b]{3}{*}{ Locus/dye } & \multirow[b]{3}{*}{$\mathrm{MgCl}_{2}(\mathrm{mM})$} & \multirow[b]{3}{*}{$\mathrm{T}\left({ }^{\circ} \mathrm{C}\right)$} & & & \multicolumn{4}{|c|}{ Gene diversity } & \multicolumn{4}{|c|}{ Allelic richness } \\
\hline & & & \multicolumn{2}{|c|}{ No. of alleles } & \multicolumn{2}{|c|}{ Brolga } & \multicolumn{2}{|l|}{$\underline{\text { Sarus }}$} & \multicolumn{2}{|c|}{ Brolga } & \multicolumn{2}{|l|}{ Sarus } \\
\hline & & & Brolga & Sarus & Gulf & Table & Gulf & Table & Gulf & Table & Gulf & Table \\
\hline Gamp3/FAM & 1.5 & 59 & 7 & 6 & 0.618 & 0.654 & 0.162 & 0.229 & 6.994 & 6.965 & 3.183 & 2.875 \\
\hline Gam $\mu 18 /$ HEX & 1.5 & 53 & $3^{1}$ & 1 & 0.224 & 0.363 & 0.000 & 0.000 & 2.943 & 3.000 & 1.000 & 1.000 \\
\hline Gam $\mu 24 /$ HEX & 2.25 & 60 & 5 & $5^{1}$ & 0.578 & 0.628 & 0.204 & 0.338 & 4.943 & 4.998 & 3.732 & 4.000 \\
\hline Gam $\mu 101 \mathrm{~b} / \mathrm{HEX}$ & 2 & 59 & 4 & 3 & 0.173 & 0.203 & 0.349 & 0.326 & 3.000 & 2.566 & 2.273 & 2.999 \\
\hline GjM8/FAM & 2 & 59 & 3 & 3 & 0.159 & 0.265 & 0.157 & 0.125 & 2.996 & 2.910 & 2.254 & 2.000 \\
\hline GjM13/HEX & 2 & 60 & $5^{1}$ & $3^{1}$ & 0.722 & 0.557 & 0.498 & 0.042 & 5.000 & 3.815 & 2.276 & 1.875 \\
\hline GjM15/FAM & 2 & 59 & 9 & 5 & 0.794 & 0.757 & 0.552 & 0.539 & 8.994 & 8.251 & 4.422 & 4.000 \\
\hline GjM48b/HEX & 2 & 56 & $8^{1}$ & $6^{1}$ & 0.559 & 0.571 & 0.160 & 0.362 & 6.999 & 7.853 & 3.039 & 3.862 \\
\hline GR $22^{2} / \mathrm{HEX}$ & & 60 & $11^{1}$ & 5 & 0.625 & 0.566 & 0.448 & 0.434 & 7.937 & 8.430 & 2.575 & 2.875 \\
\hline GR2 $25^{2} /$ Cyanine 3 & & 60 & 5 & 3 & 0.727 & 0.741 & 0.512 & 0.442 & 5.000 & 5.000 & 2.996 & 2.000 \\
\hline
\end{tabular}

${ }^{1}$ Heterozygote deficiency.

${ }^{2}$ Multiplexed.

TABLE 3 The number of brolgas, sarus cranes and sarolgas observed across 46 sites on the Atherton Tablelands in Queensland, Australia (Fig. 1) during 2013-2016.

\begin{tabular}{|c|c|c|c|c|c|}
\hline $\begin{array}{l}\text { Life history } \\
\text { stage }\end{array}$ & $\begin{array}{l}\text { No. of brolgas } \\
(\%)\end{array}$ & $\begin{array}{l}\text { No. of sarus cranes } \\
(\%)\end{array}$ & $\begin{array}{l}\text { No. of sarolgas } \\
(\%)\end{array}$ & Unidentified $^{*}$ & Total no. of cranes (\%) \\
\hline Adult & $24,870(55.8)$ & $12,245(27.5)$ & $84(0.2)$ & & $37,199(83.5)$ \\
\hline First-year juvenile & $2,491(5.6)$ & $1,136(2.5)$ & $0(0)$ & & $3,627(8.1)$ \\
\hline Total & $27,361(61.4)$ & $13,381(30)$ & $84(0.2)$ & $3,728(8.4)$ & $44,554(100)$ \\
\hline
\end{tabular}

${ }^{*}$ Because of poor weather/light conditions.

As there was the possibility that feathers of a particular bird were collected more than once, identical genotypes were identified using Cervus 3.o.7 (Kalinowski et al., 2007). Consequently, 41 samples (16 Gulf Plains, 24 Atherton Tablelands, 1 captive reference A. antigone gillae that was identical to its sibling) were excluded from the following analyses. In 11 of these cases the same genotype was found in both localities. In these cases the sample from the Atherton Tablelands was excluded arbitrarily. Missing data were not considered to be problematic, as only $16.2 \%$ of the birds had missing data and only two of the nine potential hybrids lacked data (at one locus each). It was not possible to distinguish siblings from non-siblings because the genetic variance would be too large given the moderate number of markers.

To identify the number of genetic clusters and potential hybrid individuals we conducted Bayesian clustering using STRUCTURE 2.3.4 (Pritchard et al., 2000; Falush et al., 2007), with $K$ (number of clusters) ranging from one to five and 10 replicates, assuming the admixture model and, in different runs, either uncorrelated or correlated allele frequencies. The Markov chains ran for 550,000 generations, including a burn-in of 50,000. Pilot runs with longer Markov chains yielded identical results. We used Structure Harvester 0.6.94 (Earl \& von Holdt, 2012) to analyse the data, following Evanno et al. (2005), and STRUCTURE PLOT V2.o (Ramasamy et al., 2014) and Adobe Illustrator $\mathrm{CS}_{4}$ (Adobe Systems Inc., San José, USA) to render the graphical output. We defined individuals with admixture Q of 0.1-0.9 as hybrids, following Devitt et al. (2011). These thresholds were considerably more conservative in our analysis as we used 10 loci, compared to three used by Devitt et al. (2011). However, this restriction was necessary because the loci used by Devitt et al. (2011) had speciesspecific alleles whereas the two species of cranes we compared shared some alleles. We did not attempt to identify different classes of hybrids ( $\mathrm{F}_{1}, \mathrm{~F}_{2}$ and their backcrosses) because this would have required genotyping at least 50 loci (Fitzpatrick, 2012) and we had only 10 available. The Bayesian clustering approach was validated by $k$-means clustering, which, in contrast to STRUCTURE, is free of assumptions about population genetics, using GenoDive $2.0 b_{23}$ (Meirmans \& van Tienderen, 2004). Individuals were clustered based on their allele frequencies according 
to the pseudo $F$ statistic of Caliński \& Harabasz (1974; see also Meirmans, 2012).

More detailed population genetic analyses were conducted based on the clusters identified by Bayesian clustering, including descriptive statistics and tests for Hardy-Weinberg equilibrium, linkage disequilibrium, null alleles, and population differentiation, using FSTAT 2.9.3.2 (Goudet, 1995), GenePop 4.2 (Raymond \& Rousset, 1995; Rousset, 2008) and Micro-Checker 2.2 (Van Oosterhout et al., 2004). We estimated gene flow using the formula $\mathrm{Nm}=\left[\left(1 / \mathrm{F}_{\mathrm{ST}}\right)-1\right] / 4$ (where $\mathrm{Nm}$ is the number of effective migrants) as well as based on private alleles; i.e. alleles occurring only in one subpopulation (Barton \& Slatkin, 1986), the latter in GenePop. Probabilities that two individuals were identical were calculated using Cervus, assuming either that the two birds were unrelated or, more conservatively, that they were full siblings (Waits et al., 2001). In multiple tests, $\alpha$ was Bonferroni corrected.

\section{Lincoln-Petersen index}

We applied the Lincoln-Petersen index to our 'genetically re-trapped' birds $\left(\mathrm{n}_{\text {Gulf }} \times \mathrm{n}_{\text {Tablelands }} / \mathrm{n}_{\text {both }}\right)$ based on methodology described by Southwood \& Henderson (2000).

\section{Results}

\section{Field observations}

Our observations of cranes on the Atherton Tablelands are summarized in Table 3 and Fig. 2. Of 40,826 cranes identifiable to species level (of a total of 44,554 observations), only 84 were classified as morphologically intermediate sarolgas (0.205\%). Variation among these intermediate birds meant it was not possible to assess the extent of potential hybridization (Plate 3).

Our observations of identifiable hybrids on the Atherton Tablelands were concentrated in a relatively small number of areas (Fig. 2), including Innot Hot Springs, Tumoulin/ Kaban, Hastie's Swamp and the Mareeba Wetlands. Figure 2 also illustrates that although they occur in mixed flocks, brolgas and sarus cranes are differentially distributed across the Atherton Tablelands, with higher numbers of sarus cranes concentrated on more fertile volcanic soils closer to Atherton itself, and both brolgas and putative hybrids occurring predominantly in areas of lower intrinsic fertility.

At sites with higher counts of either brolgas or sarus cranes, the species with smaller numbers in the flock tended to have proportionally more first-year juveniles (Table 4; $\chi^{2}$ tests: $\mathrm{P}<0.0001$ in both cases), potentially increasing opportunities for interactions between species while juveniles are at a critical age for pair-bonding.

\section{Population genetics}

In all STRUCTURE analyses the highest $\Delta K$ resulted from assuming two clusters, and this was confirmed by $k$-means clustering. These clusters corresponded well to the species brolga and sarus crane, as indicated by the reference birds (Fig. 3). As allele frequencies apparently differed considerably between the species, we based the subsequent analyses on the STRUCTURE model assuming uncorrelated frequencies. Although the majority of birds were either pure brolga or pure sarus crane, some were admixed (Fig. 3).

According to our criteria, 239 samples belonged to brolgas (90 Gulf Plains, 149 Atherton Tablelands) and 101 to sarus cranes (77 Gulf Plains, 24 Atherton Tablelands). Nine individuals (2.58\%; 4 Gulf Plains, 5 Atherton Tablelands) had Q scores of $0.125-0.888$ (reference: brolga) and were identified as hybrids (Fig. 3), a proportion c. 10 times greater than in our field observations. Four hybrids had alleles occurring only in brolgas at one or two loci, indicating that hybrids are fertile and can interbreed at least with brolgas or other hybrids.

After exclusion of reference birds and hybrids, we analysed the species separately, dividing both into two subpopulations corresponding to the localities. Genetic diversity is summarized in Table 2. Genetic diversity and allelic richness were both considerably higher in brolgas. Brolgas also exhibited 26 private alleles, 1-6 per locus, whereas sarus cranes had only eight private alleles, and four loci did not have any. This translates into much lower probabilities that two individuals will carry the same genotype in brolgas than in sarus cranes. The probabilities of finding two unrelated individuals with identical genotypes were $7.1 \times 10^{-7}$ for brolgas and 0.0012 for sarus cranes. Assuming the individuals were full siblings, these probabilities increased to 0.0023 and 0.0395 , respectively. In brolgas and sarus cranes, four and three loci, respectively, deviated from the HardyWeinberg equilibrium and the same loci had indications of null alleles. However, this was probably because there was a relatively high number of rare alleles (frequency $<5 \%$ ) in both species, and therefore it was not considered to be problematic for our analyses. In any case, the general results of the STRUCTURE analysis did not change after exclusion of these loci. Linkage disequilibrium did not play a role in either species. In both species, subpopulations were hardly differentiated, with $F_{\mathrm{ST}}=0.010$ (95\% CI $\left.0.003-0.020\right)$ in brolgas and $0.047(-0.006-0.136)$ in sarus cranes. The significant result for brolgas is probably attributable to sample size and is not biologically relevant. Estimates of migration based on the private allele method were high in both species, with 6.56 and 7.75 migrants per generation for brolgas and sarus cranes, respectively. Transforming $\mathrm{F}_{\mathrm{ST}}$ into estimates of migration using the formula $\mathrm{Nm}=\left[\left(1 / \mathrm{F}_{\mathrm{ST}}\right)-1\right] / 4$, we inferred 24.75 and 5.07 migrants, respectively. 

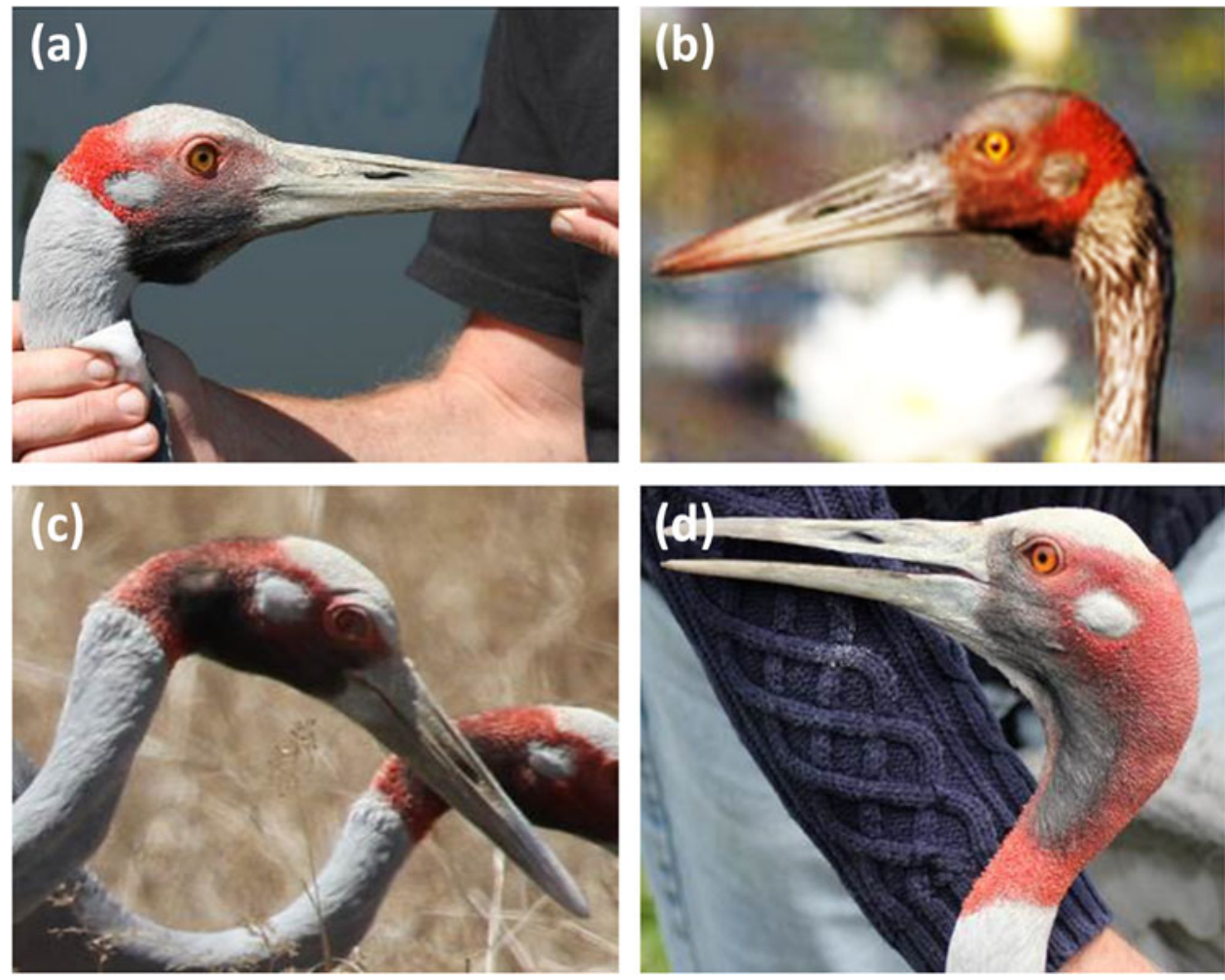

Plate 3 Heads and necks of typical species phenotypes and presumed hybrids. (a) Typical brolga; (b) sarolga (this bird was congruent with a typical brolga, except that it had pink legs, slightly more red on the nape of the comb than is typical of brolgas, and a very small, almost non-existent wattle; this combination of characters had not hitherto been recorded); (c) typical sarolga, with much shorter neck comb and slight wattle; and (d) typical Australian sarus crane. (Photos a, c \& d: T. Nevard; b: B. Johnson)
TABLE 4 Total number of cranes (and \% juveniles) at sites dominated by either brolgas or sarus cranes.

\begin{tabular}{lcc}
\hline & $\begin{array}{l}\text { No. of brolgas } \\
\text { (\% juveniles) }\end{array}$ & $\begin{array}{l}\text { No. of sarus cranes } \\
\text { (\% juveniles) }\end{array}$ \\
\hline Brolga-dominated sites & $25,510(8.8)$ & $2,273(14.5)$ \\
Sarus-dominated sites & $1,851(13.3)$ & $11,308(8.9)$ \\
Total & $27,361(9.1)$ & $13,581(9.8)$ \\
\hline
\end{tabular}

\section{Lincoln-Petersen index}

In 11 cases the same genotypes were collected at both Miranda Downs in the Gulf Plains and at Innot Hot Springs in the southern Atherton Tablelands. Of these, nine were attributable to brolgas and two to sarus cranes. According to the probabilities of encountering two individuals carrying identical genotypes by chance with our sample sizes, only the two sarus cranes could be cases of chance identity, provided the birds were siblings (see above). Applying the Lincoln-Petersen index $\left(\mathrm{n}_{\text {Gulf }} \times \mathrm{n}_{\text {Tablelands }} / \mathrm{n}_{\text {both }}\right.$; Southwood \& Henderson, 2000) to these results implies that at least 1,473 brolgas and 923 sarus cranes could have moved between the Gulf Plains and Atherton Tablelands.

\section{Discussion}

Since Archibald's first observation of brolga-sarus crane hybrids in 1972 (Archibald, 1981), local observers have continued to note the presence of apparent hybrids amongst dry season, non-breeding crane flocks on the Atherton Tablelands (Matthiessen, 2002) and elsewhere. We have shown that natural hybridization between brolgas and sarus cranes is happening and occurs more widely than is visually detectable. As hybridization is still relatively rare and brolgas and sarus cranes are differentially distributed on the Atherton Tablelands (Fig. 2), its evolutionary influence could potentially be relatively limited. However, a closer look at the allele combinations in the hybrids suggests that introgression could become more widespread. Four of the birds had alleles that occur only in brolgas at one or two loci. Although one of these birds had a membership index of 0.5, suggestive of being an F1-hybrid, these pure brolga combinations indicate that the birds are hybrids of a later generation with a hybrid parent that back-crossed with a brolga or another hybrid. Sarolgas therefore appear to be fertile at several generational recombinations.

Longitudinal research on Darwin's finches Geospiza spp. has shown that they evolved from a common ancestor in the Galápagos archipelago in the last 2 million years (Grant \& Grant, 2008), with both natural selection and introgressive hybridization being key processes in their evolution. At this stage it is not possible to predict the trajectory of brolga/ sarus crane introgression but Lamichhaney et al. (2016) demonstrated that introgression at only a single locus may have important evolutionary consequences. Interaction of introgression and selection may be complex and locality dependent, as shown for the European crow Corvus corone 


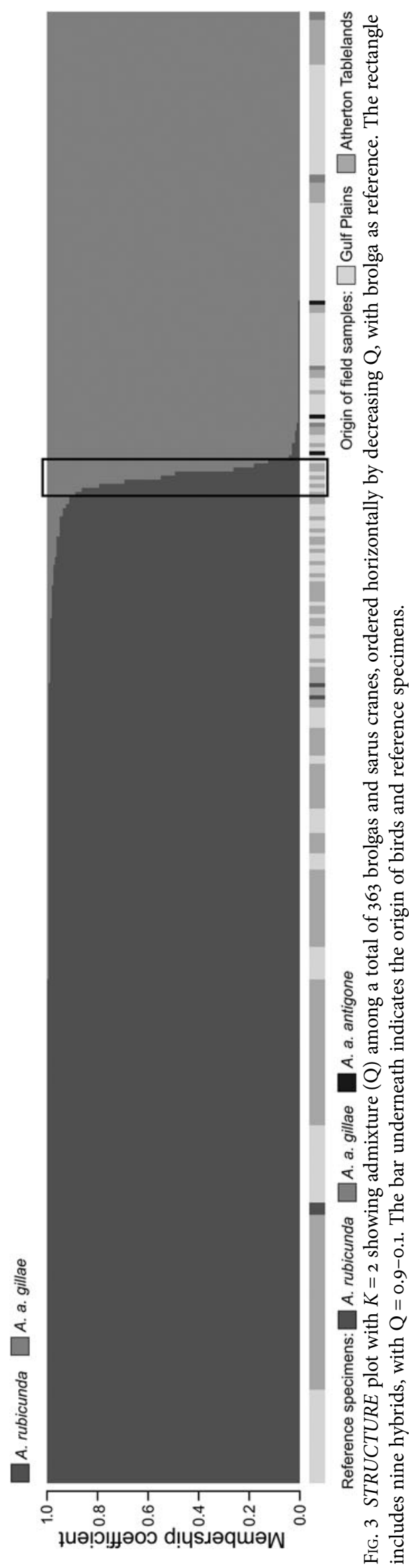

(Vijay et al., 2016), in which genetic and phenotypic differentiation varies significantly across its range, with some boundaries being firm and others mobile. Ongoing brolga/ sarus crane introgression may provide alleles to either species that could facilitate their adaptation to environmental changes brought about by such stresses as climate change or agricultural intensification; however, whether the larger body size of hybrids identified by Archibald (1981) confers a selective advantage over the parental species, potentially leading to its displacement, cannot yet be determined.

The current Australian population of sarus cranes appears to have increased relatively rapidly from what is thought to have been small numbers in northern Australia since its formal identification in the 1960s (Gill, 1967). Archibald (1981) estimated the sarus crane population was c. 200 on the Atherton Tablelands in 1972, when he identified at least two and possibly six potential brolga-sarus crane hybrids (Archibald, 1981).

Crops have been grown in northern Australia since the late 19th century and agriculture expanded substantially on the Atherton Tablelands in the 1960s, soon after Gill's first observation of sarus cranes. Templeton et al. (1990) found that changes in landscapes can be associated with genetic consequences, including introgression, which threatens species integrity (e.g. kākāriki Cyanorhamphus spp., Triggs \& Daugherty, 1996, and black-eared miners Manorina melanotis, Clarke et al., 2001). Landscape features and heterogeneity can also be reflected in population genetic structure within and across species (Miller \& Haig, 2010; Safner et al., 2011), and often changes in landscape are associated with habitat loss, contributing to population decline and possibly resulting in changes in the genetic diversity of remaining populations (Templeton et al., 1990; Keyghobadi, 2007).

That the species with fewer individuals in a mixedspecies flock has proportionally more first-year juveniles means that young brolgas and sarus cranes are more exposed to one another other at a time when imprinting is important (Horwich, 1996). This may make pairing with the other species more likely. The enduring pair bond and longevity in both species (Johnsgard, 1983) suggests that, once formed, hybrid pairs could contribute numerous hybrid offspring to the population. Although we cannot yet predict the trajectory of crane introgression in northern Australia, there are clear conservation implications. The sarus crane is thought to be declining in much of its Asian range, particularly in Burma, Thailand and Indochina (Meine \& Archibald, 1996; Archibald et al., 2003). The maintenance of Australian sarus crane populations and their genetic integrity may therefore provide security for the species should populations continue to decline in Asia. However, there seems to be no practical way of eliminating Australian crane introgression in the wild, as (1) hybrids are not necessarily visually distinguishable in the field, (2) Australian 
cranes occur in remote and inaccessible areas, and (3) the underlying behavioural stimuli are not yet understood. If related to anthropogenically driven land-use change, brolgas and sarus cranes may be brought into ever-closer and more frequent foraging and flocking proximity, potentially leading to more opportunities for hybridization. Therefore, should the maintenance of genetically pure populations of Australian sarus cranes and northern Australian brolgas be considered desirable for conservation purposes, one or more well-managed extralimital populations may need to be established. As far as we know, the only captive flock of Australian sarus cranes is in Lemgo, Germany, whose ancestry dates from a wild capture in the 1970s. This could potentially form a nucleus for a captive metapopulation, spread across several institutions. Establishing a flock managed to maintain its genetic variability at this stage could also serve as insurance against climate change impacts, with some models predicting a potential $91 \%$ decline in climatic suitability for the Australian sarus crane by 2085 (Garnett et al., 2013).

As we have collected feathers from what appear to be the same birds in both the Gulf Plains and Atherton Tablelands, considering the low probabilities of encountering genetically identical individuals, we have been able to confirm what has hitherto only been assumed by birdwatchers in North Queensland, that cranes migrate between breeding areas in the Gulf Plains and the Atherton Tablelands, a distance of c. $500 \mathrm{~km}$. There appears to be no material genetic difference between Gulf Plains and Atherton Tablelands cranes, indicated by estimates of population differentiation and migration after exclusion of the duplicate genotypes. The conservation implications of this are significant, as both areas will need to be targeted with appropriate conservation measures to ensure the survival of north Queensland's brolgas and sarus cranes. There are currently no laws protecting species that migrate within Australia (Runge et al., 2017).

The identification of identical birds in both the Gulf Plains and Atherton Tablelands based on shed feathers highlights the potential of genetic analyses to explore migration patterns and potential trends, not only in Australian cranes but also in other species. Although our collection of feathers was opportunistic rather than deliberately random and our estimates using the Lincoln-Petersen index are therefore necessarily indicative, they are of the same order as other estimates of crane populations on the Atherton Tablelands (Brolga 800-2,000 counted, 1,473 calculated; sarus crane $800-1,500$ counted, 973 calculated). Similarly to the use of non-invasive genetic monitoring techniques elsewhere, such as for large carnivores in Europe (Kaczensky et al., 2012), feather genetics could contribute to the assessment of population trends and movements of cranes within the Atherton Tablelands and between the Atherton Tablelands and other locations where either species occurs.
Although feathers have the advantage of being a noninvasive means of gathering genetic data on individuals, as noted by Hou et al. (2018), the probability of detecting hybrids was $>10$ times greater using genetic analysis rather than visual observation. However, the boundaries between pure and hybridized birds are unclear and are probably indefinable given that hybrids are fertile, meaning that introgression may have reached the point where it has no clear thresholds. A subject of future research could therefore be the definition of the relationship between genetics and phenological expression, using the feathers of known birds with hybrid phenotypes, and using data from more than the 10 loci we had available (Fitzpatrick, 2012). In addition, genomic approaches targeting coding loci (Payseur \& Rieseberg, 2016) would provide a deeper insight into the evolutionary consequences of the hybridization, as the example of Darwin's finches has shown (Lamichhaney et al., 2016). However, to obtain DNA of sufficient quality and in the necessary quantities would necessitate catching many more cranes to obtain tissue and blood samples.

Whilst acknowledging that the proportion of apparent hybrids identifiable by observers is likely to be an order of magnitude lower than are actually present in the crane population, both visual observation and analysis of shed feathers could provide valuable collateral data to monitor the trajectory of Australian crane introgression.

Acknowledgements We acknowledge the assistance of many people who have made this work possible, including Elinor Scambler and John Grant, who shared their insights on cranes on the Atherton Tablelands and Gulf Plains; Inka Veltheim and Adam Miller in relation to brolgas in Victoria; Silke Fregin, who managed our large number of samples and laboratory work at the University of Greifswald; Annabelle Olsson, who facilitated veterinary health clearance for our samples to be sent to Germany; Harry, Ruairidh and Bronwen Nevard, and Dominic and Vera von Schwertzell, who assisted with sample collection; Hans Rehme of Lemgo, who provided access to his collection of cranes; Tom and Tanya Arnold (Miranda Downs cattle station), the Waddell family (Woodleigh cattle station), Terry Trantor, Nick Reynolds, the Godfrey family and Fay Moller-Nielsen, who all provided access to their farms; and Angela Freeman of the North Queensland Wildlife Trust, who provided funding for laboratory costs.

Author contributions Conception of research, fieldwork, sample collection, data analysis, writing: TDN; sample collection, supervision of laboratory work, genetic analysis, writing: $\mathrm{MH}$; first identified the sarolga, facilitation of research, writing: GA; GIS-based mapping, data analysis, writing: IL; institutional supervision, facilitation of research, data analysis, writing: STG.

\section{Conflicts of interest None.}

Ethical standards The research was carried out in accordance with Charles Darwin University Animal Ethics Committee's approval A13019 and Queensland Department of Environment and Heritage Protection Scientific Purposes Permit WISP13984714. Export of samples to Greifswald University was undertaken under Australian Customs permit ACLTEM47 K and CITES permit PWS2014-AU001240. The authors abided by the Oryx Code of Conduct for authors. 


\section{References}

Allendorf, F.W., Leary, R.F., Spruell, P. \& WenburG, J.K. (2001) The problems with hybrids: setting conservation guidelines. Trends in Ecology \& Evolution, 16, 613-622.

Archibald, G.W. (1981) Introducing the sarolga. In Crane Research Around the World. Proceedings of the International Crane Symposium at Sapporo, Japan in 1980 and Papers From the World Working Group on Cranes (eds J.C. Lewis \& H. Masatomi), pp. 213-215. International Council for Bird Preservation.

Archibald, G.W., Sundar, K.S.G. \& Barzen, J. (2003) A review of the three subspecies of sarus cranes Grus antigone. Journal of Ecological Society, 16, 5-15.

Arnold, M.L. (1997) Natural Hybridization and Evolution. Oxford University Press, Oxford, UK.

B arrett, G., Silcocks, A., Barry, S. \& Poulter, R. (2003) The New Atlas of Australian Birds. Royal Australasian Ornithological Union, Melbourne, Australia.

BARTON, N.H. \& SLATKIN, M. (1986) A quasi-equilibrium theory of the distribution of rare alleles in a subdivided population. Heredity, 56, 409-415.

Birdife International \& NatureServe (2014) Bird Species Distribution Maps of the World. Http://datazone.birdlife.org/site/ search [accessed 8 August 2018].

Birdife International (2016) Antigone antigone. In The IUCN Red List of Threatened Species 2016: e.T22692064A93335364. Http:// dx.doi.org/10.2305/IUCN.UK.2016-3.RLTS.T22692064A93335364.en [accessed 8 August 2018].

Burke, J.M. \& Arnold, M.L. (2001) Genetics and the fitness of hybrids. Annual Review of Genetics, 35, 31-52.

Caliński, R.B. \& Harabasz, J. (1974) A dendrite method for cluster analysis. Communications in Statistics, 3, 1-27.

Clarke, R.H., Gordon, I.R. \& Clarke, M.F. (2001) Intraspecific phenotypic variability in the black-eared miner (Manorina melanotis); human-facilitated introgression and the consequences for an endangered taxon. Biological Conservation, 99, 145-155.

Department of the Environment and Energy (2012) Interim Biogeographic Regionalisation for Australia, Version 7419 Sub Regions. Commonwealth of Australia, Canberra, Australia.

Department of Transport and Main Roads (2016) State Controlled Roads - Queensland. Department of Transport and Main Roads, Brisbane, Australia.

Devitt, T.J., Baird, S.J.E. \& Moritz, C. (2011) Asymmetric reproductive isolation between terminal forms of the salamander ring species Ensatina eschscholtzii revealed by fine-scale genetic analysis of a hybrid zone. BMC Evolutionary Biology, 11, 245.

Dowling, T.E. \& SeCor, C.L. (1997) The role of hybridization and introgression in the diversification of animals. Annual Review of Ecology and Systematics, 28, 593-619.

Earl, D.A. \& von Hold T, B.M. (2012) STRUCTURE HARVESTER: a website and program for visualizing STRUCTURE output and implementing the Evanno method. Conservation Genetics Resources, 4, 359-361.

Evanno, G., Regnaut, S. \& Goudet, J. (2005) Detecting the number of clusters of individuals using the software STRUCTURE: a simulation study. Molecular Ecology, 14, 2611-2620.

Falush, D., Stephens, M. \& Pritchard, J.K. (2007) Inference of population structure using multilocus genotype data: dominant markers and null alleles. Molecular Ecology Notes, 7, 574-578.

FitZPATRICK, B.M. (2012) Estimating ancestry and heterozygosity of hybrids using molecular markers. BMC Evolutionary Biology, 12, 131.

FrankLin, D.C. (2008) Report 9: The waterbirds of Australian tropical rivers and wetlands. In A Compendium of Ecological Information on Australia's Northern Tropical Rivers (eds G.P. Lukacs \& C.M. Finlayson).
Sub-project 1 of Australia's Tropical Rivers-an Integrated Data Assessment and Analyses (DET18). A report to Land \& Water Australia, National Centre for Tropical Wetland Research, Townsville, Queensland, Australia.

Garnett, S.T. \& Crowley, G.M. (2000) The Action Plan for Australian Birds 200o. Environment Australia, Canberra. Australia.

Garnett, S.T., Franklin, D.C., Ehmke, G., VanDerWal, J.J., Hodgson, L., PAvey, C. et al. (2013) Climate Change Adaptation Strategies for Australian Birds. National Climate Change Adaptation Research Facility, Gold Coast, Australia.

Gill, H.B. (1967) The first record of the sarus crane in Australia. Emu, $69,49-52$.

GoudeT, J. (1995) FSTAT (version 1.2): a computer program to calculate F-statistics. Journal of Heredity, 86, 485-486.

Grant, J.D.A. (2005) Recruitment rate of sarus cranes (Grus antigone) in northern Queensland. Emu, 105, 311-315.

Grant, P.R. \& Grant, B.R. (2008) How \& Why Species Multiply: The Radiation of Darwin's Finches. Princeton University Press, Princeton, USA and Oxford, UK.

Grant, P.R. \& Grant, B.R. (2016) Introgressive hybridization and natural selection in Darwin's finches. Biological Journal of the Linnean Society, 117, 812-822.

Gray, A.P. (1958) Bird Hybrids. Commonwealth Agricultural Bureau, Farnham Royal, UK.

HARDING, C. (2001) Use of remote sensing and geographic information systems to predict suitable breeding habitat for the brolga Grus rubicundus in south-west Victoria. BSc thesis. Centre for Environmental Management, University of Ballarat, Victoria, Australia.

Hasegawa, O., Ishibashi, Y. \& Abe, S. (200o) Isolation and charcterization of microsatellite loci in the red-crowned crane Grus japonensis. Molecular Ecology, 9, 1677-1678.

Herring, M.W. (2005) Threatened Species and Farming. Brolga: Management of Breeding Wetlands in Northern Victoria. Arthur Rylah Institute for Ecological Research, Heidelberg, Australia.

Herring, M.W. (2007) Brolga Breeding Habitat: Managing Wetlands on your Farm. Murray Catchment Management Authority, Albury, Australia.

HoRWICH, R.H. (1996) Imprinting, attachment, and behavioral development in cranes. In Cranes: Their Biology, Husbandry and Conservation (eds D.H. Ellis, G.F. Gee \& C.M. Mirande), pp. 117-122. Department of the Interior, National Biological Service/International Crane Foundation, Washington, DC, USA.

Hou, X., Xu, P., Lin, Z., D’Urban-Jackson, J., Dixon, A., Bold, B. et al. (2018). An integrated tool for microsatellite isolation and validation from the reference genome and their application in the study of breeding turnover in an endangered avian population. Integrative Zoology, 13, 553-568.

Hughes, M.R. \& Blackman, J.G. (1973) Cation content of salt gland secretion and tears in the brolga Grus rubicundus (Perry) (Aves: Gruidae). Australian Journal of Zoology, 21, 515-518.

JohnsGard, P.A. (1983) Cranes of the World. Indiana University Press, Bloomington, USA.

Jones, K.L., Barzen, J.A. \& Ashley, M.V. (2005) Geographical partitioning of microsatellite variation in the sarus crane. Animal Conservation, 8, 1-8.

Kaczensky, P., Guillaume, C., Huber, D., Andrén, H. \& Linnell, J. (2012) Status, Management and Distribution of Large Carnivores Bear, Lynx, Wolf and Wolverine in Europe. European Commission, Brussels, Belgium.

Kalinowski, S.T., Taper, M.L. \& Marshall, T.C. (2007) Revising how the computer program CERVUS accommodates genotyping 
error increases success in paternity assignment. Molecular Ecology, 16, 1099-1106.

Keyghobadi, N. (2007) The genetic implications of habitat fragmentation for animals. Canadian Journal of Zoology, 85, 1049-1064.

Kingsford, R.T., Porter, J.L. \& Halse, S.A. (2012) National Waterbird Assessment. Waterlines report. National Water Commission, Canberra, Australia.

Koch, E.L., Neiber, M.T., Walther, F. \& Hausdorf, B. (2017) High gene flow despite opposite chirality in hybrid zones between enantiomorphic door-snails. Molecular Ecology, 26, 3998-4012.

Krajewsi, C., Sipiorski, J.T. \& Anderson, F.E. (2010) Complete mitochondrial genome sequences and the phylogeny of cranes (Gruiformes: Gruidae). The Auk, 127, 440-452.

Lamichinaney, S., Han, F., Berglund, J., Wang, C., Almén, M.S., Webster, M.T. et al. (2016) A beak size locus in Darwin's finches facilitated character displacement during a drought. Science, 352, $470-474$.

Lavery, H.J. \& Blackman, J.G. (1969) The cranes of Australia. Queensland Agricultural Journal, 95, 156-162.

Marchant, S. \& Higgins, P.J. (eds) (1993) Handbook of Australian, New Zealand and Antarctic Birds. Volume 2. Raptors to Lapwings. Oxford University Press, Melbourne, Australia.

Matthiessen, P. (2002) The Birds of Heaven: Travels with Cranes. The Harvill Press, London, UK.

Meares, K., Dawson, D.A., Horsburgh, G.J., Glenn, T.C., Jones, K.L., BRAUN, M.J. et al. (2009) Microsatellite loci characterized in three African crane species (Gruidae, Aves). Molecular Ecology Resources, 9, 308-311.

Meine, C.D. \& Archibald, G.W. (eds) (1996) The Cranes: Status Survey and Conservation Action Plan. IUCN, Gland, Switzerland, and Cambridge, UK.

Meirmans, P.G. (2012) AMOVA-based clustering of population genetic data. Journal of Heredity, 103, 744-750.

Meirmans, P.G. \& van Tienderen, P.H. (2004) GENOTYPE and GENODIVE: two programs for the analysis of genetic diversity of asexual organisms. Molecular Ecology Resources, 4, 792-794.

Menkhorst, P., Rogers, D., Clarke, R., Davies, J., Marsack, P. \& Franklin, K. (2017) The Australian Bird Guide. CSIRO Publishing, Clayton South, Australia.

Miller, A. (2016) The Development of Microsatellite Loci through Next Generation Sequencing, and a Preliminary Assessment of Population Genetic Structure for the Iconic Australian Crane, Brolga (Antigone rubicunda). Nature Glenelg Trust, Warrnambool, Victoria.

Miller, M.P. \& Haig, S.M. (2010) Identifying shared genetic structure patterns among pacific northwest forest taxa: insights from use of visualization tools and computer simulations. PLOS ONE, 5, e13683.

Miller, S.A., Dykes, D.D. \& Polesky, H.F. (1988) A simple salting out procedure for extracting DNA from human nucleated cells. Nucleic Acids Research, 16, 1215.

NeI, M. (1987) Molecular Evolutionary Genetics. Columbia University Press, New York, USA.

Payseur, B.A. \& Rieseberg, L.H. (2016) A genomic perspective on hybridization and speciation. Molecular Ecology, 25, 2337-2360.

Pennisi, E. (2016) Shaking up the tree of life. Science, 354, 817-821.

Petit, R.J., El Mousadik, A. \& Pons, O. (1998) Identifying populations for conservation on the basis of genetic markers. Conservation Biology, 12, 844-855.
Pritchard, J.K., Stephens, M., \& Donnelly, P. (2000) Inference of population structure using multilocus genotype data. Genetics, 155 , 945-959.

Ramasamy, R.K., Ramasamy, S., Bindroo, B.B. \& Naik, V.G. (2014) STRUCTURE PLOT: a program for drawing elegant STRUCTURE bar plots in user friendly interface. SpringerPlus, 3, 431.

Raymond, M. \& Rousset, F. (1995) GENEPOP (version 1.2): population genetics software for exact tests and ecumenicism. Journal of Heredity, 86, 248-249.

Rhymer, J.M. \& Simberloff, D. (1996) Extinction by hybridization and introgression. Annual Review of Ecology and Systematics, 27, 83-109.

Rieseberg, L.H., Archer, M.A. \& Wayne, R.K. (1999) Transgressive segregation, adaptation and speciation. Heredity, 83, 363-372.

RousSET, F. (2008) Genepop'oo7: a complete reimplementation of the Genepop software for Windows and Linux. Molecular Ecology Resources, 8, 103-106.

Runge, C.A., Martin, T.G., Possingham, H.P., Willis, S.G. and Fuller, R.A. (2014) Conserving mobile species. Frontiers in Ecology and the Environment, 12, 395-402.

Runge, C.A., Gallo-Cajiao, E., Carey, M.J., Garnett, S.T., Fuller, R.A. \& McCormack, P.C. (2017) Coordinating domestic legislation and international agreements to conserve migratory species: a case study from Australia. Conservation Letters, 10, 765-772.

Safner, T., Miller, M.P., McRae, B., Fortin, M.J. \& Manel, S. (2011) Comparison of Bayesian clustering and edge detection methods for inferring boundaries in landscape genetics. International Journal of Molecular Science, 12, 865-889.

Soltis, P. \& Soltis, D.E. (2009) The role of hybridization in plant speciation. Annual Review of Plant Biology, 60, 561-588.

Southwood, T.R.E. \& Henderson, A. (200o) Ecological Methods. 3rd edition. Blackwell Science Ltd, Oxford, UK.

Templeton, A.R., Shaw, K., Routman, E. \& Davis, S.K. (1990) The genetic consequences of habitat fragmentation. Annals of the Missouri Botanical Garden, 77, 13-27.

Todesco, M., Pascual, M.A., Owens, G.L., Ostevik, K.L., Moyers, B.T., HÜBNER, S. et al. (2016) Hybridization and extinction. Evolutionary Applications, 9, 892-908.

Toews, D.P.L. \& Brelsford, A. (2012) The biogeography of mitochondrial and nuclear discordance in animals. Molecular Ecology, 16, 3907-3930.

Triggs, S.J. \& Daugherty, C.H. (1996). Conservation and genetics of New Zealand parakeets. Bird Conservation International, 6, 89-101.

Van Oosterhout, C., Hutchinson, W.F., Wills, D.P.M. \& SHIPLEY, P. (2004) MICRO-CHECKER: software for identifying and correcting genotyping errors in microsatellite data. Molecular Ecology Notes, 4, 535-538.

Vijay, N., Bossu, C.M., Poelstra, J.W., Weissensteiner, M.H., Suh, A., Kryukov, A.P. \& Wolf, J.B.W. (2016) Evolution of heterogeneous genome differences across multiple contact zones in a crow species complex. Nature Communications, 7, 13195.

Waits, L.P., Luikart, G. \& Taberlet, P. (2001) Estimating the probability of identity among genotypes in natural populations: cautions and guidelines. Molecular Ecology, 10, 249-256.

Walkinshaw, L.H. (1973) Cranes of the World. Winchester Press, New York, USA.

Wood, T.C. \& Krajewski, C. (1996) Mitochondrial sequence variation among the subspecies of Sarus Crane (Grus antigone). The Auk, 113, 655-633. 